This is not the version of record. The final published version of Honnurvali M.S., Gupta N., Goh K., umar T. (2020) Measurement, Modeling and Simulation of Photovoltaic Degradation Rates. In: Goel N., Hasan S., Kalaichelvi V. (eds) Modelling, Simulation and Intelligent Computing. MoSICom 2020. Lecture Notes in Electrical Engineering, vol 659. Springer, Singapore. ISBN: 9789811547744 ISSN: 1876-1100 (print) ISSN: 1876-1119 (electronic) can be found at https://doi.org/10.1007/978-981-15-4775-1_7 


\title{
Measurement, Modelling, and Simulation of Photovoltaic degradation rates
}

\author{
Mohamed Shaik Honnurvali ${ }^{10000-0002-9402-8500]}$, Naren Gupta ${ }^{2}$ and Keng Goh ${ }^{2[0000-0001-}$ \\ 5205-5802] and Tariq umar ${ }^{3[0000-0002-1197-8181]}$ \\ ${ }^{1,3}$ Asharqiyah University, Ibra 400, Sultanate Of Oman \\ ${ }^{2}$ Edinburgh Napier University, Edinburgh EH105DT, United Kingdom \\ honnur.vali420@gmail.com
}

\begin{abstract}
Photovoltaic degradation rates play a vital role in visualizing and analyzing the performance of the PV modules over the long run. These degradation rates provide critical information for the stakeholders and researchers to make sensible decisions in deploying the best photovoltaics suitable in those concerned geographical regions of the globe. A site survey is conducted to calculate PV degradation rates. The results have shown that for the first three years since the initial installation, the degradation rates have remained in line with the manufacturer values (i.e. less than $0.6 \%$ ) while the next two years the degradation rates have almost increased by $40 \%$. This is due to discoloration of the encapsulant causing the reduction of the short circuit current $\left(\mathrm{I}_{\mathrm{sc}}\right)$. Mathematically modeling such visual loss factors have not considered so far. The visual loss factor equation is developed and incorporated in the output current equation of the PV module. Further, the I-V and P-V curves are simulated and compared with the measured I-V curves. The results have shown an acceptable error percentage of around $0.3 \%$.
\end{abstract}

Keywords: PV (photovoltaics), STC (Standard test conditions), Short circuit current $\left(I_{s c}\right)$.

\section{Introduction}

The key initiatives adopted by most of the countries globally, to limit the carbon emissions and further rise in the global temperatures, has created an impact in revising the energy generation methods [1]. Different renewable energy technologies are being integrated into the current energy generation system and also in planning future energy needs [2],[3],[4]. The progress on the renewable energy still suffer from a number of challenges in many contries including the Arabian Gulf region [5]. One of the most prominent and widely deployed renewable technology currently is solar photovoltaics systems [6]. The solar photovoltaic systems have attracted the largest investments share in renewable energies around 161 billion USD dollars [7] which accounted for 58\% of the new renewable energy investments. These investments are majorly witnessed in developing countries rather than in developed countries. As a result, production capabilities have increased far more thereby reducing the cost of PV systems. According to 
the market predictions, the solar photovoltaic system installations will be tripled in the next four to five years. An emphasis on the solar market globally in terms of cost, employment, environmental preserving factors are very well explained in [7], [8]. It is also anticipated that by 2050 most of the future smart cities globally would be able to meet their energy demands by $100 \%$ renewable energy generation methods [9]. Considering the bright future and huge investments made in photovoltaics, it is vital to understand the performance of the photovoltaic systems over a period of time. Earlier research studies conducted in the different parts of the globe [10], [11], [12] have witnessed photovoltaic degradation due to the influence of various factors such as local environment conditions and other socio-economic factors. A recent research study by Mohamed shaik et.al [13], [14] conducted a survey of around $130 \mathrm{PV}$ modules to estimate the degradation rates in Oman. The observed degradation rate overall is $1.96 \%$ which is almost the double the degration rates seen in European countries. Further, their study has observed that the modules installed in hot and humid climatic zones has seen with higher degradation rate than that of other climatic zones. On the other hand, by PV technology type thin film modules has seen with lowest degradation rates. The estimation of the photovoltaic degradation rates will help the local stakeholders, researchers and investors to gain an insight into the photovoltaics reliability and performance under the local climatic and other socio-economic factors. It also helps in estimating the return on investments and predict the decline of output power delivery over time. In this paper, a mathematical function estimating the short circuit current $\left(\mathrm{I}_{\mathrm{sc}}\right)$ reduction due to visual effects is developed and used to calculate the final output current of the PV module. The reduction in short circuit current further decreases the maximum output power $\left(\mathrm{P}_{\max }\right.$. Section two explains the experimental setup and the methodology to measure the I-V and P-V curves from the site. Section three presents the mathematical model to calculate the visual loss factor, modified output current equation for the PV module and the simulation performed in Matlab to estimate the degradation rates. Section four discusses and compares the results observed in detail. Section five presents the conclusion of the paper.

\section{Experimental Setup and Estimation of PV $\left(P_{\max }\right)$ degradation rates:}

Sultanate of Oman, one of the GCC countries with abundant irradiance, long day duration with clear skies are all favorable factors to deploy solar technology to generate energy. Despite the hot and robust climatic conditions [15], [16] the performance and reliability of the photovoltaic modules have not been investigated thoroughly in Oman. On the other hand, several studies have been conducted in this regard in different parts of the world. According to the research study report by [17], [18] different PV technologies in different parts of the world have observed degradation. Implicitly, these degradation rates depend on the local climatic conditions and other socio-economic factors such as quality, installation type, and maintenance. To understand the performance and reliability of the photovoltaic modules in the sultanate of Oman, A survey is conducted every year in the month of July since 2014 to record the I-V curves. The measurements 
are taken at two different irradiances from mid-noon around $12 \mathrm{PM}$ and the other at post noon around 2:00 PM to 2:30 PM.

\subsection{Site description}

The site is located near the muscat city (google coordinates: $23^{\circ} 35^{\prime} 00.6^{\prime \prime} \mathrm{N}$ $58^{\circ} 21^{\prime} 37.9^{\prime \prime E}$ ). The purpose of this solution to provide energy to the base transceiver station (BTS) supporting the local telecom network (Omantel). This solution is an offgrid solution which has a system size of around $1.4 \mathrm{KW}$. The energy is stored using a $24 \mathrm{~V}$ battery connected with the MPPT charge controller and inverter. Six SUNTECH $240 \mathrm{~W}_{\mathrm{p}}$ PV Panels are mounted to the aluminum stand to supply the required energy. The key characteristics of the PV module at STC (standard test conditions) conditions are shown in table 1 . The experimental setup to measure the I-V and P-V curves is shown in the figure. 1. To measure the I-V and P-V curves of a PV module, "MECO 9018 BT" portable solar analyzer is used. Besides that, an irradiance meter, temperature sensor, current and voltage sensors are used to record the corresponding values during the measurement. The environmental conditions in the Sultanate of oman usually remain hot and dusty (due to desert climate) for the most part of the year. Before performing measurements, the PV modules are cleaned with water and sodium detergent to remove the dust accumulation. The study of dust effects on the maximum output

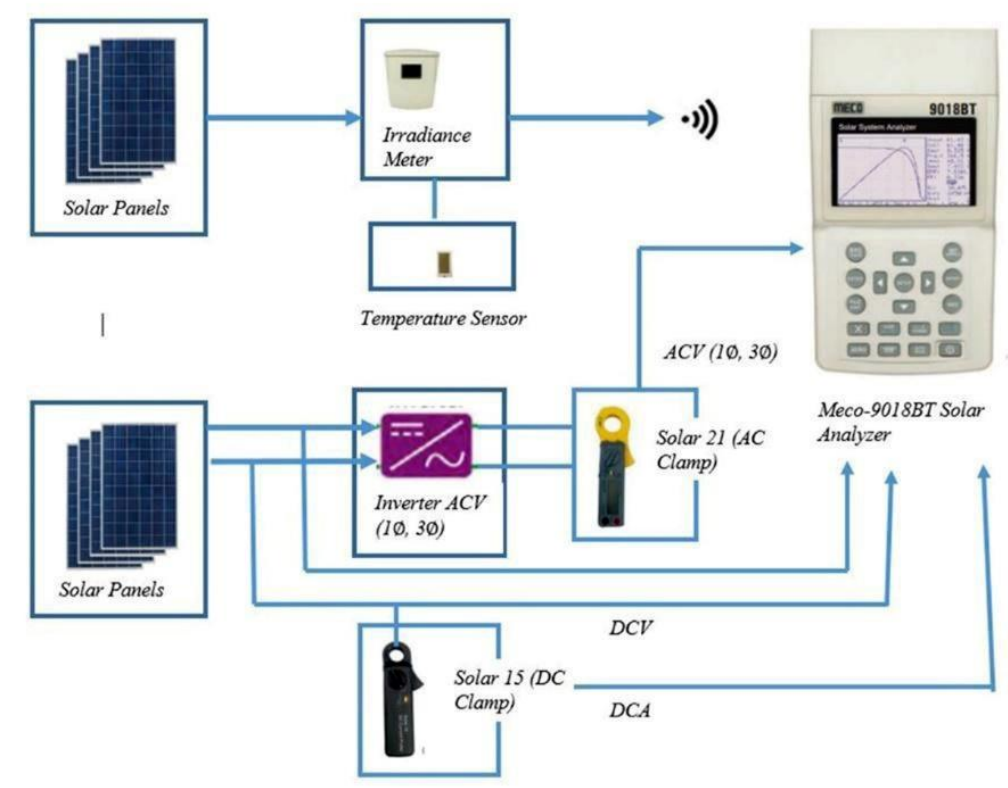

Fig. 1. Experimental setup to measure the I-V and P-V curves at the site. 
Table 1. SUNTECH 240Wp PV panel datasheet

\begin{tabular}{ll}
\hline Parameters & $\begin{array}{l}\text { Key specifica- } \\
\text { tions }\end{array}$ \\
\hline Max Power at STC (Pm) & $240 \mathrm{~W}$ \\
Maximum power voltage(Vmp) & $30.2 \mathrm{~V}$ \\
Maximum power current(Imp) & $7.95 \mathrm{~A}$ \\
Open circuit voltage (Voc) & $37.2 \mathrm{~V}$ \\
Shortcircuit current (Isc) & $8.43 \mathrm{~A}$ \\
No. of cells in & 60 \\
Series & 1 \\
No. of cells in parallel & 1.2 \\
Ideality factor (n) & $0.055 \%{ }^{\circ} \mathrm{C}$ \\
Temperature coefficient of Isc & \\
(Ki) & $25^{\circ} \mathrm{C}$ \\
Reference Temperature & 1000 \\
Solar irradiance & Polycrystalline \\
(w/m²) & \\
PV technology type &
\end{tabular}

power is not considered in our study. The maintenance of the PV modules is highly recommended by the client for the smooth and efficient performance of the PV modules. Generally, a maintenance contract is provided by the supplier to the client, where regular inspection and cleaning of PV modules occur on a monthly basis. However, a recent study [19] conducted in six cities of northern Oman has noted the PV output power drop is around $60 \%$ if not cleaned for a month. The PV modules are short-circuited for about five minutes and thermally inspected by using an infrared camera to detect any hotspots formation or any faulty cell in the PV module. The I-V and P-V curves are recorded for each PV module at two different irradiances. The irradiance measurements recorded at noontime stood around $800 \mathrm{w} / \mathrm{m}^{2}$ with a tolerance level of \pm $50 \mathrm{w} / \mathrm{m} 2$. Similarly, in the post noon, the recording stood at around $600 \mathrm{w} / \mathrm{m}^{2}$ with the same tolerance level. 'Photovoltaic degradation' is a common phenomenon that is observed in PV modules. These degradations mainly occur due to several factors that are discussed in the literature [20], [21]. The PV degradation rates are highly influenced by the local environmental factors and the environmental conditions vary from region to region all across the globe. Table.2. shows the maximum output power $\left(\mathrm{P}_{\max }\right)$ of the measured P-V curves by each year since 2014. PV degradation rate is calculated by the equation (1) as given below:

$P_{\text {max }}$ Degradation rate $=\frac{P_{(\text {max }, \text { intial value })}-P_{(\text {max }, \text { final value })}}{P_{(\max , \text { initial value })} \times \text { Age of the } \text { module }} \% /$ year

The average degradation rate for the six modules under the irradiance $800 \mathrm{w} / \mathrm{m}^{2}$ is observed to be at $1.09 \%$ since the initial installation. while with irradiance $600 \mathrm{w} / \mathrm{m}^{2}$, the 
degradation rates seen is $1.10 \%$. both values at different irradiances show good accuracy which confirms the correctness in the estimation of the degradation rates. The observed degradation rates seem to be higher than the degradation rates seen in other countries [22], [23]. The reasons are mainly due to discoloration of the encapsulant which causes the reduction in the short circuit current $\left(\mathrm{I}_{\mathrm{sc}}\right)$ thus decreasing the maximum output power $\left(\mathrm{P}_{\max }\right)$. The hot and humid climatic conditions play a very prominent role in discoloration of encapsulant and delamination of the front panel due to high salt sodium formations. Therefore, regular maintenance is recommended for the efficient performance of the PV panels.

Table 2. Average PV degradation rates per year of the six PV modules

\begin{tabular}{|c|c|c|c|c|c|c|c|c|}
\hline \multirow{2}{*}{$\begin{array}{l}\text { PV module } \\
\text { sample }\end{array}$} & \multirow{2}{*}{$\begin{array}{c}\text { Meas- } \\
\text { ured Ir- } \\
\text { radi- } \\
\text { ance } \\
\mathrm{w} / \mathrm{m}^{2} \\
\end{array}$} & \multicolumn{6}{|c|}{ Year } & \multirow{2}{*}{$\begin{array}{l}P_{\max } \text { degra- } \\
\text { dation rate } \\
\text { per year (in } \\
\% \text { ) }\end{array}$} \\
\hline & & $\begin{array}{l}2014 \\
\left(\mathrm{P}_{\max }\right) \text { in } \\
\mathrm{W} \\
(\text { initial })\end{array}$ & $\begin{array}{l}2015 \\
\left(\mathrm{P}_{\max }\right. \\
) \text { in } \\
\mathrm{W} \\
\end{array}$ & $\begin{array}{l}2016 \\
\left(\mathrm{P}_{\max }\right) \\
\text { in } \mathrm{W}\end{array}$ & $\begin{array}{l}2017 \\
\left(\mathrm{P}_{\max }\right. \\
) \text { in } \\
\mathrm{W}\end{array}$ & $\begin{array}{l}2018 \\
\left(\mathrm{P}_{\max }\right. \\
) \text { in } \\
\mathrm{W}\end{array}$ & $\begin{array}{l}2019 \\
\left(\mathrm{P}_{\max }\right) \\
\text { in } \mathrm{W} \\
(\text { Final })\end{array}$ & \\
\hline \multirow{2}{*}{ Module 1} & 800 & 170 & 169 & 168 & 166 & 164 & 162.5 & 0.89 \\
\hline & 600 & 140 & 139 & 138 & 137 & 136 & 134 & 0.85 \\
\hline \multirow[t]{2}{*}{ Module 2} & 800 & 172 & 171 & 170 & 168 & 166 & 164 & 0.93 \\
\hline & 600 & 146 & 145 & 143 & 141 & 140 & 139 & 0.95 \\
\hline \multirow[t]{2}{*}{ Module 3} & 800 & 168 & 167 & 165 & 164 & 161 & 159 & 1.07 \\
\hline & 600 & 145 & 143 & 141 & 140 & 139 & 137 & 1.10 \\
\hline \multirow[t]{2}{*}{ Module 4} & 800 & 162 & 161 & 160 & 159 & 157 & 154 & 0.98 \\
\hline & 600 & 142 & 141 & 140 & 138 & 137 & 135 & 0.98 \\
\hline \multirow[t]{2}{*}{ Module 5} & 800 & 189 & 188 & 186 & 184 & 180 & 178 & 1.16 \\
\hline & 600 & 150 & 149 & 148 & 147 & 145 & 142 & 1.06 \\
\hline \multirow[t]{2}{*}{ Module 6} & 800 & 180 & 178 & 177 & 175 & 174 & 171 & 1.0 \\
\hline & 600 & 152 & 152 & 151 & 149 & 147 & 144 & 1.05 \\
\hline \multirow{2}{*}{$\begin{array}{l}\text { Average deg- } \\
\text { radation for } \\
\text { six modules }\end{array}$} & 800 & & & & & & & 1.09 \\
\hline & 600 & & & & & & & 1.10 \\
\hline
\end{tabular}




\section{Modeling and Simulation of PV degradation rates using Matlab:}

Through the technology advancement of both hardware and software, a system can be simulated to analyze its behavior prior to manufacturing. As a result, simulation tools have become an integral part of the design process to simulate the system performance that will correlate to the actual practical implementation in real life. However, there are challenges to the extent of incorporating all the real lifetime contributing factors into the simulation model. One such challenge is to integrate the effects of the reduction of $I_{\text {sc }}$ due to visual defects seen in the real world as discussed in section 2.1. The visual defects observed under the influence of the local climatic conditions may vary from region to region. For instance, in our study, PV modules are seen with discoloration of encapsulation and some modules with delamination of the front panel which has contributed to the reduction of short circuit current $\mathrm{I}_{\mathrm{sc}}$. Similar studies and results are discussed very well in the literature [24], [25]. In order to model the visual defects seen in our study the following equation (2) is developed using exponential curve fitting methods:

$$
V_{L F}=e^{-0.035 \times(I L F)}
$$

Where $V_{L F}$ is the visual defects loss factor, and $I L F$ is a short circuit current $\left(I_{s c}\right)$ loss factor and is given by $\left(\frac{I_{S C} \text { measured at irradiance }}{I_{S C} \text { at that irradiance under STC conditions }}\right)$.

Earlier many studies have been reported [26], [27] considering Matlab and Simulink for modeling the PV cell, panel, and also found to be a good match between the simulated and the experimental results. However, those studies did not include the physical factors that commonly play a vital role in the degradation of the PV module. The physical factors are region-dependent and may vary from place to place. Therefore, one can develop similar mathematical loss factor models according to the factors which influence the performance of the PV module. A single diode model is considered in this study as shown in figure 2 .

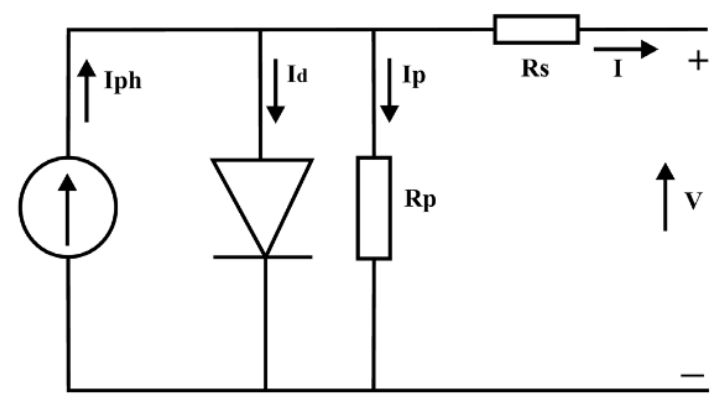

Fig. 2. Equivalent real PV cell model (single diode). 
Each solar cell in a PV module is modeled by the five parameters single diode model. Rs is the series resistance in the path of the current, which occurs mainly due to metal contacts, semiconductor materials, connecting bus tracks. On the other hand, Rp is the parallel resistances that occur due to cell thickness and surface effects. The effect of Rp is more prominent only when the number of PV modules considered in the PV system is large [28]. Therefore, Rs has been taken into consideration while Rp as infinite. The output current $I$ of a solar cell is given by equation (3) and the modified equation after considering $\mathrm{R}_{\mathrm{P}}$ as infinite is given in equation (4). As PV module consists of solar cells connected in a series-parallel manner, along with visual defects loss factor is also considered making the output current $I$ modified and illustrated as shown in equation (5).

$\mathrm{I}=\mathrm{I}_{\mathrm{Ph}}-\mathrm{I}_{\mathrm{s}}\left[\exp \left(\frac{\mathrm{q}\left(\mathrm{V}+\mathrm{IR}_{\mathrm{s}}\right)}{\mathrm{N}_{\mathrm{s}} \mathrm{KAT}_{\mathrm{o}}}\right)-1\right]-\frac{\mathrm{V}_{\mathrm{p}}+\mathrm{IR}_{\mathrm{s}}}{\mathrm{R}_{\mathrm{P}}}$

Where, $I_{p h}$ is the Photocurrent of a solar PV cell generated due to solar irradiation, $\mathrm{I}_{\mathrm{s}}$ is the saturation current, $\mathrm{V}$ is the output voltage from the PV panel, $\mathrm{q}$ is the charge of electron, $\mathrm{K}$ is boltzmann's constant, $\mathrm{A}$ is the ideality factor of the diode, $\mathrm{T}_{0}$ real-time temperature, $\mathrm{N}_{\mathrm{s}}$ is the number of cells connected in series, $\mathrm{I}$ is the output current from the $\mathrm{Pv}$ Panel, $\mathrm{R}_{\mathrm{s}}$ is the series resistance of the PV panel and $\mathrm{R}_{\mathrm{p}}$ is the parallel resistance of the PV panel.

$I=I_{P h}-I_{S}\left[\exp \left(\frac{q\left(V+I R_{S}\right)}{N_{S} K A T_{o}}\right)-1\right]$
$I=N_{P} \times I_{P h}-N_{P} \times I_{S}\left[\exp \left(\frac{q\left(V+I R_{S}\right)}{N_{S} K A T_{o}}\right)-1\right]-e^{-0.035 \times(I L F)}$

To compute the above equations, $I_{p h}, I_{r s}$ and $I_{s}$ is required which are given by equation (6), (7) and (8).

$$
\begin{aligned}
& I_{P h}=\left[I_{s c}+K_{i}\left(T_{0}-T_{r}\right)\right] \times \frac{G}{G_{r e f}} \\
& I_{r s}=I_{s c} /\left[\exp \left(\frac{q V_{o c}}{N_{s} K A T_{o}}\right)-1\right] \\
& I_{s}=I_{r s}\left[\frac{T_{0}}{T_{r}}\right]^{3} \exp \left[\left(\frac{q E_{g}}{A k}\right)\left(\frac{1}{T_{r}}-\frac{1}{T_{0}}\right)\right]
\end{aligned}
$$

Where $K_{i}$ is the temperature coefficient of $I_{s c}$ of the cell, $I_{s c}$ is the short circuit current at STC, $T_{r}$ is the reference temperature at STC, G is the measured solar irradiance, $\mathrm{G}_{\mathrm{ref}}$ is the solar irradiance at STC conditions, $\mathrm{V}_{\mathrm{oc}}$ is the open circuit voltage of the PV panel, $\mathrm{I}_{\mathrm{rs}}$ is the diode reverse saturation current, $\mathrm{E}_{\mathrm{g}}$ is the energy band gap for the silicon $(1.1 \mathrm{eV})$. Using equations (2) to (8) a Simulink model to estimate the total output current of the PV module which includes the visual losses observed on site is shown in figure. 3. further, figure.4. shows complete PV module simulation setup to estimate the output power of the PV module and I-V curves at different irradiances. 


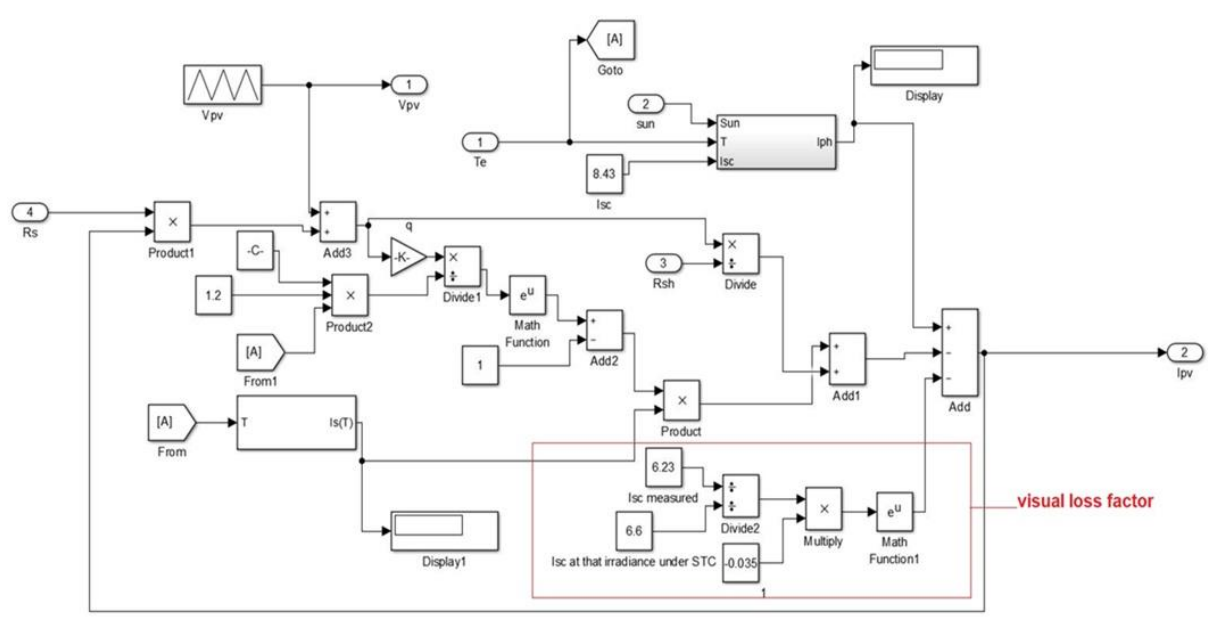

Fig. 3. Simulation of output current $I$ using Simulink with VLF (subsystem)

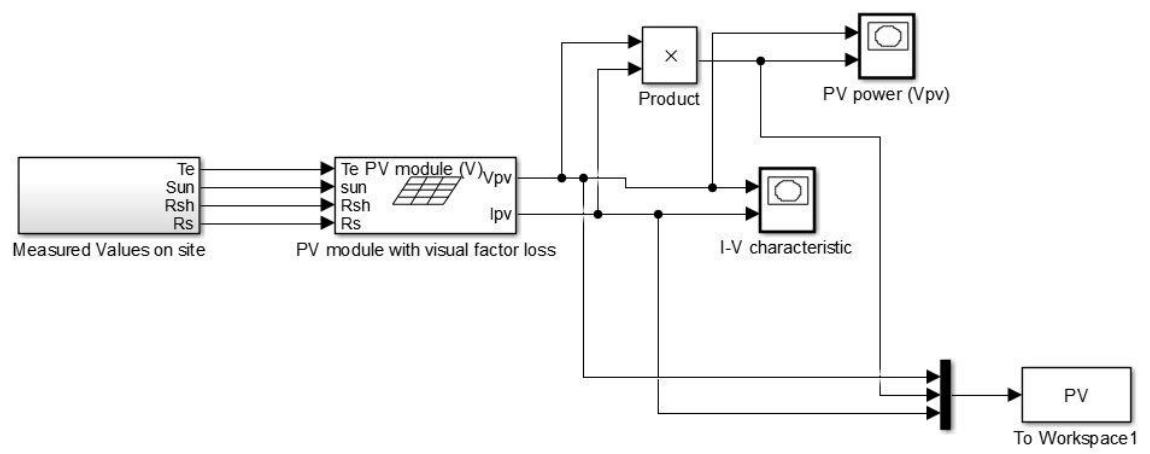

Fig. 4. Simulation of I-V and P-V curves of a PV module (Full System).

\section{$4 \quad$ Results and discussion:}

The I-V curves for a sample 5 PV module measured during the initial installation year (i.e. 2014) at two different irradiances along with the simulated I-V curves are presented in figure.5. The maximum power output $P_{\max }$ measured during the initial installation at $800 \mathrm{w} / \mathrm{m}^{2}$ irradiance is $178 \mathrm{w}$ while the simulated $\mathrm{I}-\mathrm{V}$ curve has shown a close match with an error $0.28 \%$. At $600 \mathrm{w} / \mathrm{m}^{2}$ irradiance, the error value is $0.56 \%$ which is also at a considerate level. Similarly, the I-V curves for the same PV module measured after five years of field exposure are presented in figure. 6 . The measured maximum output power is $170 \mathrm{~W}$ which has degraded at a rate of $0.89 \% / y e a r$ which is higher than the manufacturer given rate $(0.5 \%$ after 1 year). 


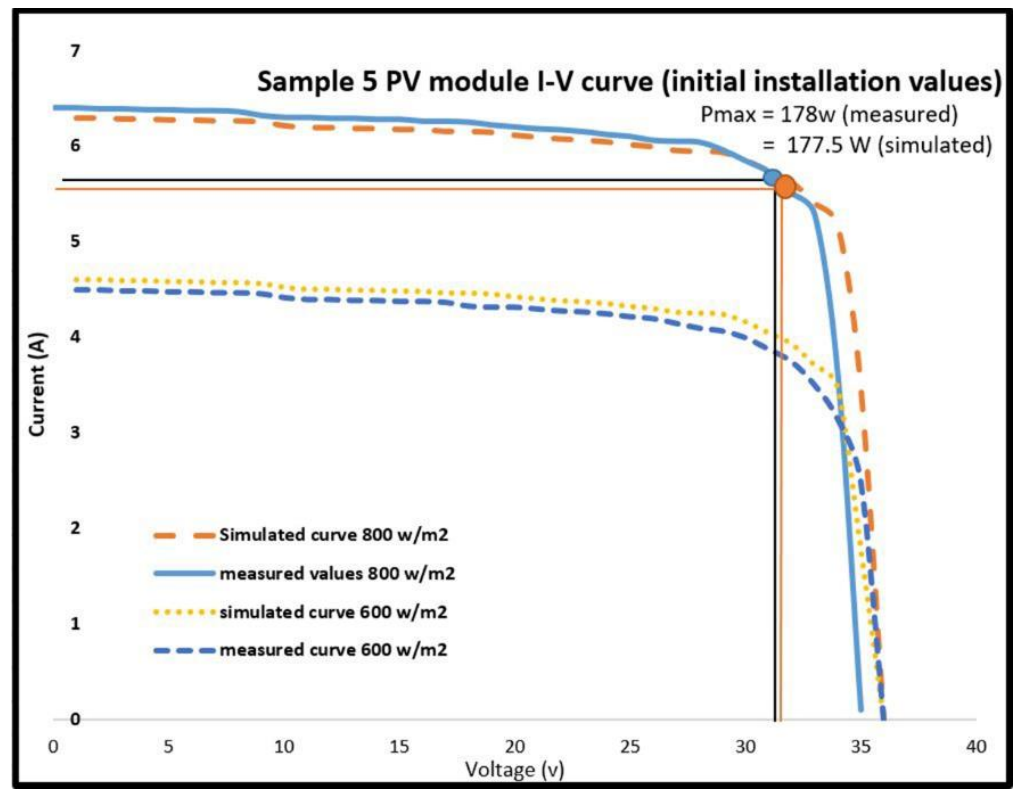

Fig. 5. Sample 5 PV module I-V curves along with the simulated curves during the initial year of installation.

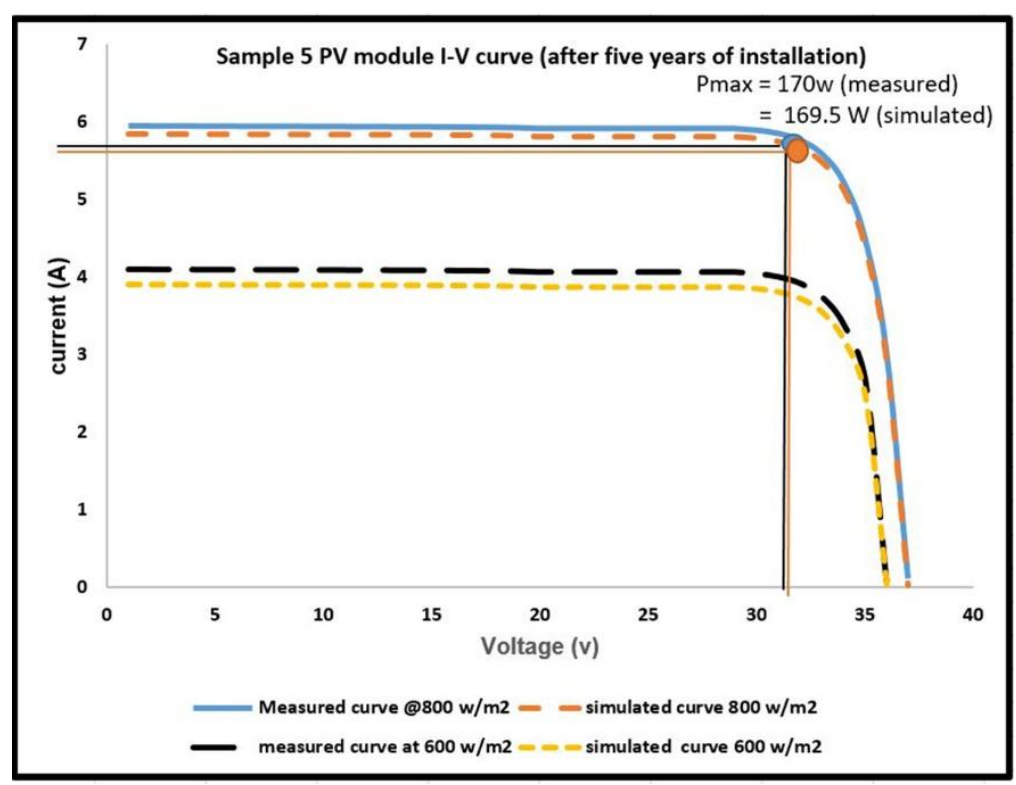

Fig. 6. Sample 5 PV module I-V curves along with the simulated curves after five years of field exposure. 
The PV degradation rates for the sample module 5 based on year-wise is shown in figure. 7. Presenting of I-V curves for the total six PV modules is not possible due to the page limitations. However, one can observe from the figure. 7 that the degradation rates for the first three years have remained at $0.56 \%$ within the manufacturer specified levels. Later on, the degradation rates have almost doubled reaching $0.9 \%$ for the next two years of the sample PV module 5. Similarly, one can visualize a similar trend seen for the remaining PV modules from table. 2.

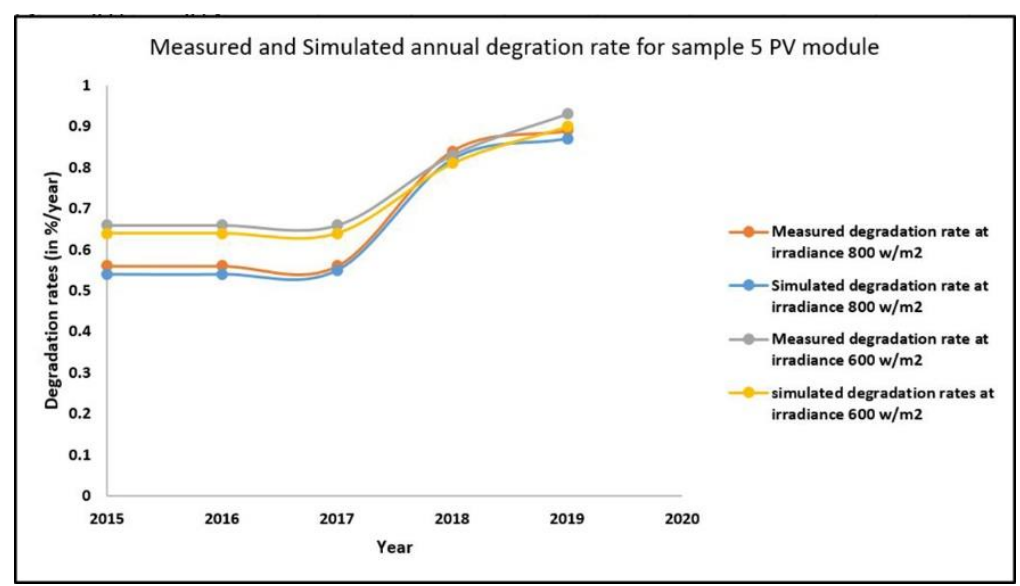

Fig. 7. Year-wise measured and simulated PV degradation rates for the sample 5 PV module.

\section{Conclusion:}

PV degradation rates for the six PV modules is calculated for a field exposure of five years in Oman. The results have shown higher degradation rates than the manufacturer proposed values. Possible reasons are due to high temperatures and salty humid climate affecting the PV module encapsulant thereby causing the reduction in short circuit current (Isc). Further, a loss factor equation is developed to incorporate the losses that occurred due to visual defects. The total output current of the PV module is modified and simulated using Matlab to validate the measured data. The results have shown a satisfactory match with an error percentage of $0.3 \%$. However, this equation modeling is dependent on factors arising from the local environmental conditions. The estimation of PV degradation will help the industry utilities to select the proper PV technology for better performance under local climatic conditions and also improvise the quality of the installation methods. The other major advantage is to accurately estimate the return of investments (ROI) for the stake holders. 


\section{References}

1. Umar, T. and Egbu, C., 2018, July. Global commitment towards sustainable energy. Proceedings of the Institution of Civil Engineers-Engineering Sustainability. Volume 172 Issue 6, September 2019, pp. 315-323 In Focus: SEB16. Thomas Telford Ltd. https://doi.org/10.1680/jensu.17.00059.

2. Umar, T. and Wamuziri, S., 2016. Briefing: Conventional, wind and solar energy resources in Oman. Proceedings of the Institution of Civil Engineers-Energy, 169(4), pp.143-147. https://doi.org/10.1680/jener.16.00011.

3. Umar, T., 2017, July. Briefing: Towards a sustainable energy: the potential of biomass for electricity generation in Oman. Proceedings of the Institution of Civil Engineers-Engineering Sustainability (Vol. 171, No. 7, pp. 329-333). Thomas Telford Ltd. https://doi.org/10.1680/jensu.17.00001.

4. Umar, T., 2018. Geothermal energy resources in Oman. Proceedings of the Institution of Civil Engineers-Energy, 171(1), pp.37-43. https://doi.org/10.1680/jener.17.00001.

5. Umar, T., Egbu, C., Ofori, G., Honnurvali, M.S., Saidani, M. and Opoku, A., 2019. Challenges towards renewable energy: an exploratory study from the Arabian Gulf region. Proceedings of the Institution of Civil Engineers-Energy, pp.1-34. https://doi.org/10.1680/jener.19.00034.

6. Umar T. Rooftop solar photovoltaic energy: a case study of India. Nanomaterials and Energy. 2017 Mar 3;6(1):17-22. https://doi.org/10.1680/jnaen.16.00002.

7. Jäger-Waldau, A., 2018. PV status report 2018. European Commission.

8. Malik, K., Rahman, S.M., Khondaker, A.N., Abubakar, I.R., Aina, Y.A. and Hasan, M.A., 2019. Renewable energy utilization to promote sustainability in GCC countries: policies, drivers, and barriers. Environmental Science and Pollution Research, pp.1-17.

9. Honnurvali, M.S., Gupta, N., Goh, K., Umar, T., Kabbani, A. and Nazecma, N., 2019, January. Can Future Smart Cities Powered by 100\% Renewables and Made Cyber Secured-A Analytical Approach. In 2019 IEEE 12th International Conference on Global Security, Safety and Sustainability (ICGS3) (pp. 206-212). IEEE.

10. Busquet, S., Kobayashi, J. and Rocheleau, R.E., 2017, June. Operation and performance assessment of grid-connected PV systems in operation in Maui, Hawaii. In 2017 IEEE 44th Photovoltaic Specialist Conference (PVSC) (pp. 1061-1066). IEEE.

11. Dhoke, A. and Mengede, A., 2017, November. Degradation analysis of PV modules operating in Australian environment. In 2017 Australasian Universities Power Engineering Conference (AUPEC) (pp. 1-5). IEEE.

12. Honnurvali, M.S. and Gupta, N., 2017, March. PV electrical parameters degradation analysis-Oman perspective. In 2017 8th International Renewable Energy Congress (IREC) (pp. 1-5). IEEE.

13. Honnurvali, M.S., Gupta, N., Goh, K., Umar, T., Kabbani, A. and Nazeema, N., 2018. Case study of PV output power degradation rates in Oman. IET Renewable Power Generation, 13(2), pp.352-360.

14. Honnurvali, M.S., Gupta, N., Goh, K., Umar, T., Kabbani, A. and Nazeema, N., 2017. Study of Photovoltaics (PV) Performance Degradation Analysis in Oman. International Journal of Sustainable Energy, 6(2), p.18.

15. Jordan, D.C., Silverman, T.J., Wohlgemuth, J.H., Kurtz, S.R. and VanSant, K.T., 2017. Photovoltaic failure and degradation modes. Progress in Photovoltaics: Research and Applications, 25(4), pp.318-326. 
16. Umar, T. and Egbu, C., 2018, June. Heat stress, a hidden cause of accidents in construction. Proceedings of the Institution of Civil Engineers-Municipal Engineer (pp. 1-12). Thomas Telford Ltd. https://doi.org/10.1680/jmuen.18.00004.

17. Umar, T., Egbu, C., Honnurvali, M.S., Saidani, M. and Al-Bayati, A.J., 2019. Briefing: Status of occupational safety and health in GCC construction. Proceedings of the Institu-tion of Civil Engineers-Management, Procurement and Law, pp.1-5. https://doi.org/10.1680/jmapl.18.00053.

18. Lopez-Garcia, J. and Sample, T., 2018. Evolution of measured module characteristics versus labelled module characteristics of crystalline silicon-based PV modules. Solar Energy, 160, pp.252-259.

19. Kazem, H.A. and Chaichan, M.T., 2019. The effect of dust accumulation and cleaning methods on PV panels' outcomes based on an experimental study of six locations in Northern Oman. Solar Energy, 187, pp.30-38.

20. Jordan, D.C., Silverman, T.J., Wohlgemuth, J.H., Kurtz, S.R. and VanSant, K.T., 2017. Photovoltaic failure and degradation modes. Progress in Photovoltaics: Research and Applications, 25(4), pp.318-326.

21. Kuitche, J.M., Pan, R. and TamizhMani, G., 2014. Investigation of dominant failure mode (s) for field-aged crystalline silicon PV modules under desert climatic conditions. IEEE Journal of Photovoltaics, 4(3), pp.814-826.

22. Sánchez-Friera, P., Piliougine, M., Pelaez, J., Carretero, J. and Sidrach de Cardona, M., 2011. Analysis of degradation mechanisms of crystalline silicon PV modules after 12 years of operation in Southern Europe. Progress in photovoltaics: Research and Applications, 19(6), pp.658-666.

23. Jordan, D.C. and Kurtz, S.R., 2013. Photovoltaic degradation rates - an analytical review. Progress in photovoltaics: Research and Applications, 21(1), pp.12-29.

24. Dubey, R., Chattopadhyay, S., Kuthanazhi, V., Kottantharayil, A., Singh Solanki, C., Arora, B.M., Narasimhan, K.L., Vasi, J., Bora, B., Singh, Y.K. and Sastry, O.S., 2017. Comprehensive study of performance degradation of field-mounted photovoltaic modules in India. Energy Science \& Engineering, 5(1), pp.51-64.

25. Jordan, D.C., Kurtz, S.R., VanSant, K. and Newmiller, J., 2016. Compendium of photovoltaic degradation rates. Progress in Photovoltaics: Research and Applications, 24(7), pp.978989.

26. Hejri, M., Mokhtari, H., Azizian, M.R., Ghandhari, M. and Söder, L., 2014. On the parameter extraction of a five-parameter double-diode model of photovoltaic cells and modules. IEEE Journal of Photovoltaics, 4(3), pp.915-923.

27. Siddique, H.A.B., Xu, P. and De Doncker, R.W., 2013, June. Parameter extraction algorithm for one-diode model of PV panels based on datasheet values. In 2013 International Conference on Clean Electrical Power (ICCEP) (pp. 7-13). IEEE.

28. Tina, G.M. and Ventura, C., 2013. Evaluation and validation of an electrical model of photovoltaic module based on manufacturer measurement. In Sustainability in Energy and Buildings (pp. 15-24). Springer, Berlin, Heidelberg. 